\title{
Design Process of Hydrolysis and Fermentation Bioethanol Production from Seaweed Eucheuma cottonii to Renewable Energy Sovereignity
}

\author{
Wagiman $^{*}{ }^{, 1}$, Makhmudun Ainuri ${ }^{1}$, Rinda Gusvita ${ }^{1}$, and Jumeri ${ }^{1}$ \\ ${ }^{1}$ Department of Agroindustrial Technology, Faculty of Agricultural Technology \\ Universitas Gadjah Mada, Jl. Flora No.1 Bulaksumur 55281, Indonesia. \\ Email: ayuafif@ugm.ac.id*
}

\begin{abstract}
The aim of this research was study of E. cottonii to produce bioethanol fermentation substrate with a high reduction sugar content and low Hidroxymethilfurfural (HMF). Fermentation done by instant yeast and Saccharomyces cerevisiae culture of FNCC 3012.The best treatment was obtained in the combination of $2 \%$ of $\mathrm{H}_{2} \mathrm{SO}_{4}$ by time reaction of 120 minutes in $80^{\circ} \mathrm{C}$ produced 15.61 $\mathrm{g} / \mathrm{l}$ reducing sugar and $5.03 \mathrm{~g} / \mathrm{l} \mathrm{HMF}$. In fermented process, the hydrolysate with instant yeast starter delivered much more efficiency in $3.63 \mathrm{ml} \mathrm{CO}$ volume, $87.53 \%$ in fermentation efficiency, and $1.96 \mathrm{~g} / \mathrm{l}$ reducing sugar on fifth day of fermentation.
\end{abstract}

Keywords: bioethanol, Eucheuma cottonii, fermentation, hydrolysis, process design

\section{INTRODUCTION}

Indonesia's seaweed production reached 4,305,027 tons (Marine and Fisheries in Figures, 2011) which potentially for the development and utilization of seaweed. In addition, the climate in Indonesia is also supportive for the growth and cultivation of seaweed so that Indonesia has a great diversity of seaweed. It has been used as a source of raw materials of food industry, pharmaceutical industry, and environmental remediation. Other utilization of seaweed is as a producer of biofuels such as bioethanol, biodiesel, and biogas. Conversion seaweed into ethanol will provide widespread impact on the national economic also increasing the income of farmers and fishermen, the increasing in revenues from exports, and strengthening the resilience of countries in the field of energy, especially renewable energy.

Seaweed is categorized into three groups: red seaweed (Rhodophyta), green seaweed (Chlorophyta), and brown seaweed (Phaeohyceae) (Percival, 1979 in Park et al., 2011). Among the three types of seaweed, red seaweed known to have a high carbohydrate content (Park et al., 2011). Carrageenan is a polysaccharide extracted from red seaweeds such as Chondrus,
Gigartina, Euchema, Furcellaria, and Phyllophora (Meinita et al. 2011). According Rachbini et al., (2011) in Nurdin (2012), a type of seaweed that is widely cultivated in Indonesia consists of Euchema cottonii and Glacilaria, with the yield ratio of about 70:30. Due to the high production of these types of seaweed, so in this study used red seaweed of the type of $E$. cottonii.

According to the results of previous studies on the seaweed group, it can be seen that the seaweed in particular of the type of $E$. cottonii can be processed into ethanol by fermentation method and utilizing carbohydrate content. Puspawati et al. (2015) conducted a seaweed E. cottonii hydrolysis using cellulase enzymes. The best reduction sugar produce after hydrolysis for 12 hours at 19 AU cellulase enzymes at $50{ }^{\circ} \mathrm{C}$ resulted in reduction sugar $7.853 \mathrm{~g} / \mathrm{l}$.

In that study, the raw material used seaweed dried first. Before hydrolyzed, dried seaweed should be smoothed beforehand to expand the surface and facilitate contact with the catalyst material. The process required energy and high cost. Therefore, in this research made efforts to simplify the production process by doing seaweed washing and soaking before hydrolysis. 


\section{MATERIAL AND METHODS}

\subsection{Material and Equipment}

\subsubsection{Material}

Dried seaweed E. cottonii was supplied from Buton, Southeast Sulawesi. The chemicals used include $\mathrm{H}_{2} \mathrm{SO}_{4}$, distilled water, glucose anhydrous, $\mathrm{NaOH}$, alcohol, and various reagents for analytical purposes such as arsenomolibdat, nelson A and B, Carrez solutions I and II, and others. Instant yeast for fermentation "Fermipan" brands imported by PT Sangra Ratu Boga, yeast inoculum FNCC 3012 from the Central Laboratory of the Inter-University, Gadjah Mada University, and Glucose Yeast Extract.

\subsection{Methods}

\subsubsection{Seaweed Characterization}

E.cottonii rinsed with distilled water to remove salt, sand and other impurities. Characterization of seaweed carried by proximate test to determine water content, fat content, protein content, ash content, and fiber content to determine the potential of $E$. cottonii as bioethanol feedstock.

\subsubsection{Hydrolysis of polysaccharides}

Seaweed must first be soaked in water for 24 hours then hydrolysed by using dilute acid $\left(\mathrm{H}_{2} \mathrm{SO}_{4}\right)$. The experiment design was randomized block design ccomplete with three factors as presented in Table 1 . The hydrolysate then neutralized by $\mathrm{NaOH}$ to $\mathrm{pH}$ 7. Furthermore, the hydrolysate was analyzed of reduction sugar Nelson-Somogyi and HMF.

\subsubsection{Fermentation}

Fermentation was done by $S$. cerevisiae yeast (Fermipan) with starters as much as $10 \%$ at $30{ }^{\circ} \mathrm{C}$ for 72 days. It also conducted a pure culture of $S$. cerevisiae FNCC 3012. Criteria for selecting the best method based on the efficiency and performance of the fermentation process.

Table 1.Treatment variations on seaweed hydrolysis process using $\mathrm{H}_{2} \mathrm{SO}_{4}$

\begin{tabular}{clccc}
\hline Notation & Parameter & Treatment 1 & Treatment 2 & Treatment 3 \\
\hline A & $\mathrm{H}_{2} \mathrm{SO}_{4}$ con. & $1 \%$ & $2 \%$ & $3 \%$ \\
\hline B & Time & 60 minutes & 90 minutes & 120 minutes \\
\hline C & Temperature & $80^{\circ} \mathrm{C}$ & $90^{\circ} \mathrm{C}$ & $100^{\circ} \mathrm{C}$ \\
\hline
\end{tabular}

\section{RESULT AND DISCUSSION}

\subsection{Characterization of $E$. cottonii}

Table 2 showed that the water content of E. cottonii from Buton was $40,73 \%$ (after solar drying). Whereas, the optimal water levels in seaweed 31-35\% for Eucheuma sp. (Anonymous, 2008). In addition, spoilage can occur if the algae has a high water content. This means that the seaweed that has a high water content has a great opportunity to experience decay if not promptly drained back. Crude fiber was the residue of food or agriculture after being treated with an acid or alkali boiling (Fardiaz et al., 1986 in Sudiaman, 1990). Crude fiber in seaweed E. cottonii amounted to $4.09 \%$. Determination of crude fiber content, in principle, that separates the coarse fiber of non-starch polysaccharides by hydrolyze. But, the acid hydrolized able to destruct all polysaccharides to glucose that can be converted into bioethanol.

Table 2. Characterization of E. cottonii Compound Concentration (\%)

\begin{tabular}{lrl}
\hline Water & 40,734 & $\pm 0,077$ \\
Ash & 33,775 & $\pm 0,043$ \\
Protein & 3,855 & $\pm 0,007$ \\
Fat & 0,078 & $\pm 0,028$ \\
Fiber & 4,087 & $\pm 0,030$ \\
Carbohydrate & 17,469 & $\pm 0,0750$ \\
\hline
\end{tabular}

\subsection{Acid Hydrolysis}

\subsubsection{Hydrolysis Process}


Pretreatment of E. cottonii was done by soaking the seaweed in water for 24 hours. The water content of seaweed is initially approximately $40.73 \%$, after being soaked for 24 hours increased to $92.42 \%$ water content. Further size reduction was done using a blender for 1 minute. Soaking and size reduction were intended that seaweed can be easily hydrolyzed. Water contained in seaweed also served as a precursor reaction. This condition made the hydrolysis reaction optimally. Preparation of raw materials as applied required less energy compared to previous studies because it did not require drying and shrinkage to form a powder.

The acid hydrolysis mechanisms of carrageenan based on protonation of the glycosidic oxygen. High temperature and acid hydrolysis reported facilitate the glyosidic bond (Khambhaty et al., 2012 in Tan et al., 2013).

\subsubsection{Reduction Sugar Content}

The reducing sugar obtained in this research was $2.94 \%$ - $15.61 \%$, the maximum achieved in combination treatment $\mathrm{H}_{2} \mathrm{SO}_{4}$ concentration of $2 \%$ with a reaction time of 120 minutes at a temperature of $80^{\circ} \mathrm{C}$. Based on analysis of variance, known that $\mathrm{H}_{2} \mathrm{SO}_{4}$ concentration, reaction time, temperature, and the interaction of these three significant effect on hydrolysis of E. cottonii..

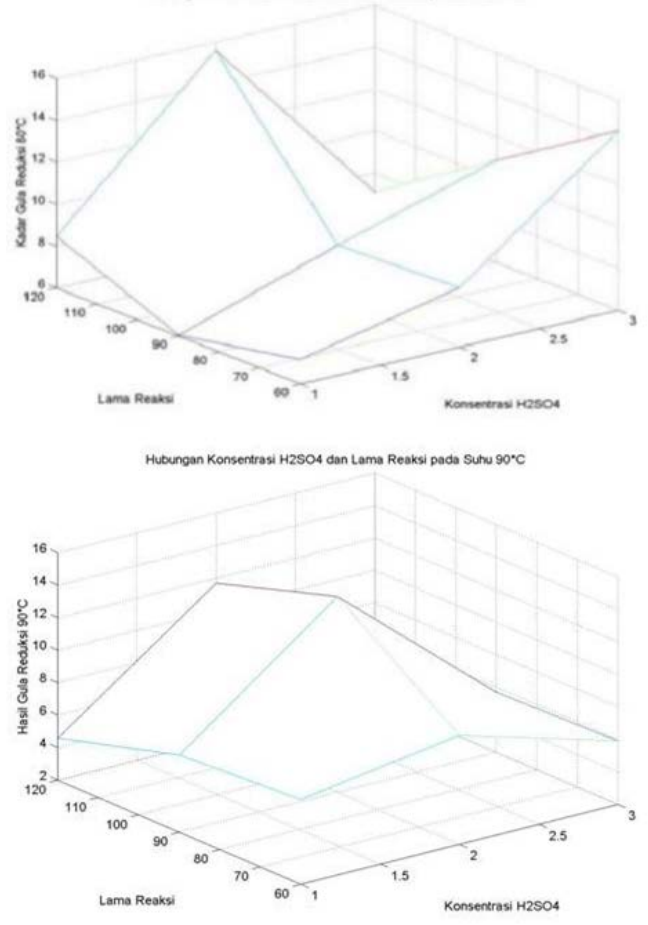

Meanwhile, treatment groups were not significantly different. Test of orthogonal polynomials indicated that treatment with $\mathrm{H}_{2} \mathrm{SO}_{4}$ concentration and reaction time increases linearly reducing sugar levels at a concentration of $1 \%$ and $2 \%$. but the $3 \%$ $\mathrm{H}_{2} \mathrm{SO}_{4}$ concentration, reducing sugar levels decreases with the time reaction

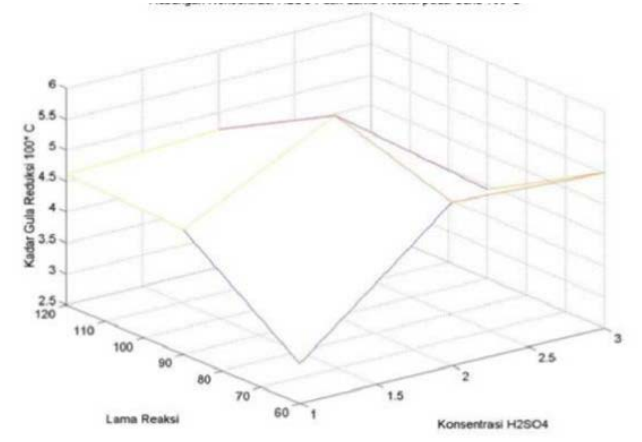

Figure 1. Reduction sugar on $80^{\circ} \mathrm{C}$ (a), $90^{\circ} \mathrm{C}$

$$
\text { (b), and } 100^{\circ} \mathrm{C}(\mathrm{c}) \text {. }
$$

Samsuri (2007) stated that the low concentrations of diluted acids may increase the quantity of sugar in the hydrolysis of lignocellulose as $\mathrm{H}^{+}$ions in strong acid may decide glycosidic bond contained in cellulose.

At higher temperatures the reaction did not lead to the formation of monomeric sugars until the yield of sugar decrease at above $120{ }^{\circ} \mathrm{C}$. The advanced reactions typically occured as long as heat treatment of the polysaccharide. This reaction could not be avoided in the state of acidic hydrolysis. This causes sugars would be decomposed and resulted in low sugar yield (Irawan, 2012). Hydrolysis in the study conducted under conditions of treatment temperature of 80 ${ }^{\circ} \mathrm{C}$ without size reduction prior to powder form. So that this condition can be applied to make it easier for small and medium-sized industry.

\subsubsection{Hydroxymethilfurfural (HMF)}

In addition to acid hydrolysis produce glucose also produce furan compounds, phenolic, and acetic acid. These products were unexpected form because it would inhibit the fermentation process. Using acid hydrolysis process could also trigger the degradation of glucose so that the glucose and ethanol yield decreased (Howard et al., 2003).

Interaction between the reaction time 
and the $\mathrm{H}_{2} \mathrm{SO}_{4}$ concentration was significant effect on levels of HMF. As polynomial trials showed that increasing the parameter observation led to increase HMF levels from hydrolysate E. cottonii. Along with the increase in the reaction temperature, there was also increased levels of HMF in a linear trend. After hydrolysis, HMF levels fall between $2.81 \mathrm{~g} / \mathrm{l}$ to $5.40 \mathrm{~g} / \mathrm{l}$. Also, the higher the concentration of $\mathrm{H}_{2} \mathrm{SO}_{4}$, the higher the levels of HMF produced in line with the duration of fermentation.

The levels of HMF closely associated with glucose levels in $E$. cottonii that has been hydrolyzed in $\mathrm{H}_{2} \mathrm{SO}_{4}$ solution. The higher the acid concentration and temperature used, and the longer the reaction that lasts the greater the levels of HMF. At high temperature and pressure, glucose will be converted into HMF. If HMF further hydrolyzed to form lavulinat acid and formic acid (Musatto and Roberto, 2004).

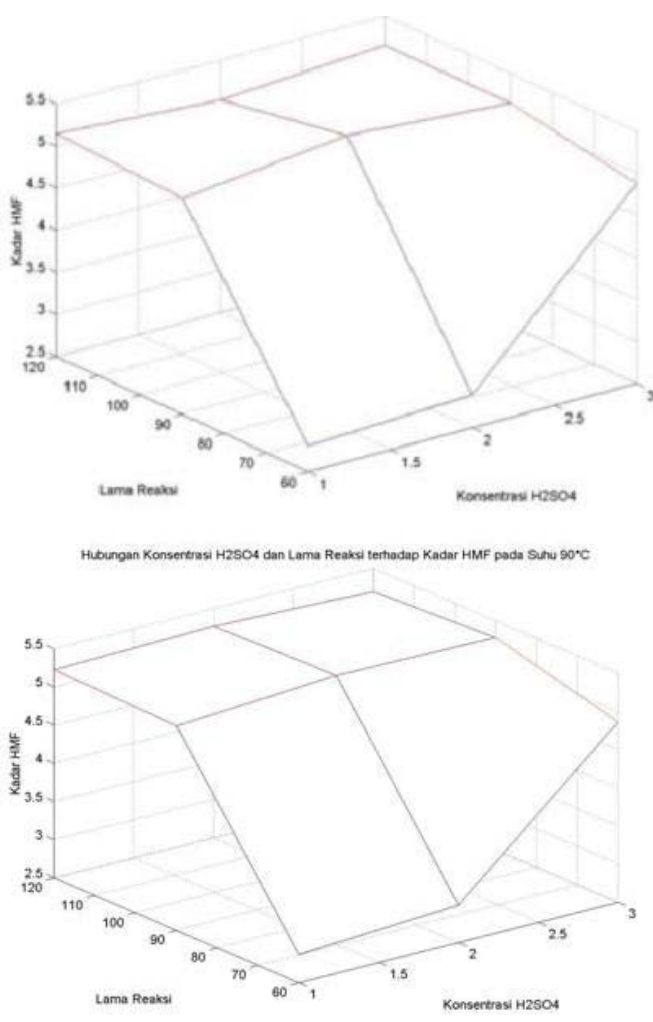

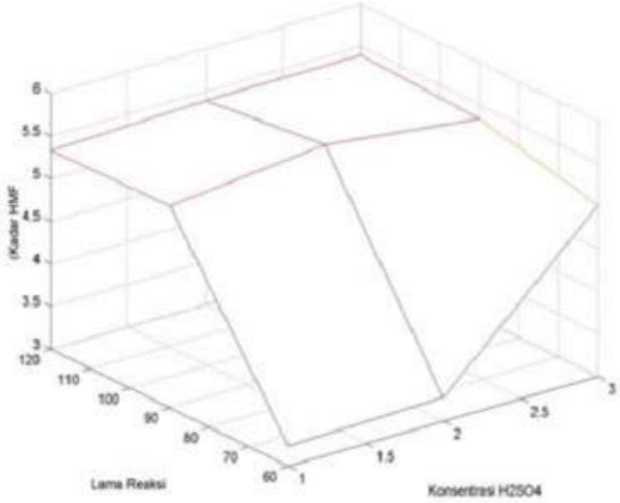

Figure 2. Concentration of $\mathrm{HMF}$ at $80^{\circ} \mathrm{C}$ (a), $90^{\circ} \mathrm{C}$ (b), and $100^{\circ} \mathrm{C}$ (c).

HMF is a reaction formation of side reactions are unavoidable in the circumstances acidic hydrolysis. The most important degradation products in terms of results and the possibility of its use is cyclic compound furfural (2-furaldehida) formed from pentose and uronat acid, and hydroksimetilfurfural (5hydroxy methyl-2- furaldehida) from hexose sugars, primarily glucose. The results were higher than these compounds obtained only in concentrated acid and high temperatures. If the temperature is raised, the molecule HMF levulinat cyclical turns into acid and formic acid (Fengel and Wegener, 1995). The compounds could inhibit the growth of microorganisms used in fermentation into ethanol. These was because glucose and other sugars that are a major component in the formation of ethanol has been degraded into other compounds that are not expected.

Meinita et al. (2012) conducted research to hydrolyze $10 \mathrm{~g}$ powdered catalyst $E$. cottonii with $\mathrm{H}_{2} \mathrm{SO}_{4} 0.2 \mathrm{M}$ as much as $100 \mathrm{ml}$. The hydrolysis yield of HMF $4.85 \mathrm{~g} / \mathrm{l}$. The results tend to be not much different from that obtained in this research produced HMF 5.03 $\mathrm{g} / \mathrm{l}$ for hydrolysis conditions that produce the highest reduction sugar.

\subsubsection{Optimal Hydrolysis Treatment}

The highest reduction sugar $15.61 \mathrm{~g} / \mathrm{l}$ was obtained on condition of hydrolysis with $\mathrm{H}_{2} \mathrm{SO}_{4} 2 \%$ for 120 minutes at a temperature of $80^{\circ} \mathrm{C}$ (A2B3C2). In this condition, the levels of HMF reached $5.03 \mathrm{~g} / \mathrm{l}$ while the 
lowest levels of HMF obtained at hydrolysis conditions using $1 \% \mathrm{H}_{2} \mathrm{SO}_{4}$ for 60 minutes at a temperature of $80^{\circ} \mathrm{C}$. While on the fermentation conditions, very low levels of reducing sugars and hemicellulose, cellulose, and lignin is not hydrolyzed properly.

Hemicellulose is hydrolyzed using low concentrations of acid (dilute) at moderate reaction conditions, but needed more extreme conditions to be able to hydrolyze cellulose. The main advantage with dilute acid hydrolysis is, no need for acid recovery, and the absence of loss of acid in the process (Iranmahboob et al., 2002). A long time the hydrolysis reaction will lead to the formation of toxic inhibitors. Glucose was degraded to form HMF and reacted further to form formic acid. While the result of the degradation of lignin will be formed phenol compounds (Palmqvist and HahnHagerdal, 2000). Those products could inhibit the growth of microorganisms in the fermentation process of ethanol formation.

\subsubsection{Fermentation Hydrolisate E. cottonii}

E. cottonii hydrolysate fermentation gel has been carried out by Chandra et al. (2011) with a reducing sugar of $15.8 \mathrm{mg} / \mathrm{mL}$ using baker's yeast capable of producing alcohol $4.6 \%$ during the 5-6 days of fermentation at room temperature. Meanwhile, in this research the fermentation was done by using the instant of $S$. cerevisiae starters as much as $10 \%$ at $30^{\circ} \mathrm{C}$ for 72 days. It also conducted a pure culture fermentation using S. cerevisiae FNCC 3012. Ethanol concentration of $1-2 \%(\mathrm{v} / \mathrm{v})$ could interfere with the fermentation and the ethanol concentration of $10 \%(\mathrm{v} / \mathrm{v})$ yeast growth rate will stop because yeast is a microorganism that is sensitive to ethanol (Clark and Mackie, 1984). According to Prescott and Dunn (1981), the maximum ethanol content that can be produced before the fermentation really stop is $13 \%(\mathrm{v} / \mathrm{v})$. Mangunwidjaja and Suryani (1994) adds that the concentration of $40 \mathrm{~g} / \mathrm{L}(4 \%)$ of ethanol would be a good inhibitor for growth of biomass and ethanol production.

In Figure 6 shows that the $\mathrm{CO}_{2}$ produced by fermentation using pure cultures of S.cerevisiae was smaller than the fermentation using yeast. This was presumably due to differences in strains and the quality of their respective cultures. From hour-12 to $36^{\text {th }}$ an increase in the rate of fermentation was demonstrated by the increasing rate of formation of CO is very sharp. In this phase conditions were optimal fermentation process to produce $\mathrm{CO}_{2}$ and high ethanol. After hours of $36^{\text {th }}$ decrease the rate of formation of $\mathrm{CO}_{2}$ which means a decline in the rate of fermentation. A decrease in the rate of fermentation was suspected because of the accumulation product is ethanol and the acid metabolite which then inhibit the rate of fermentation.

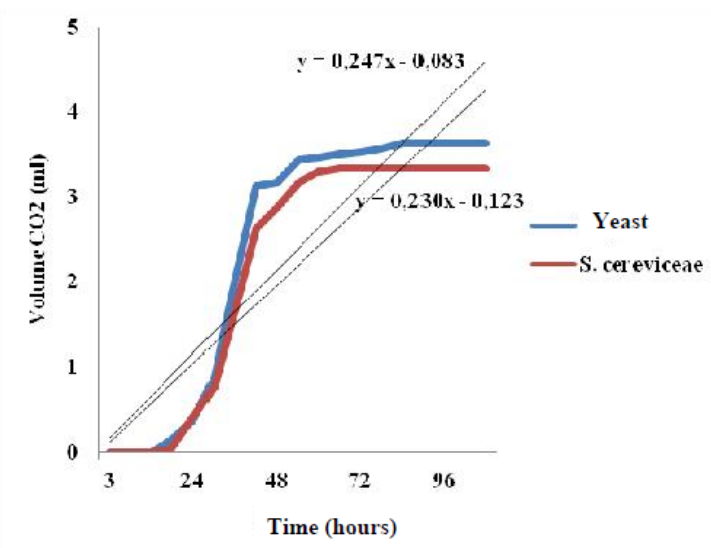

Figure 6. $\mathrm{CO}_{2}$ volume while fermentation

Decreased levels of reducing sugars indicates the use of substrate by $S$. cerevisiae during fermentation. In Figure 7 below shows that there was an increase in the consumption of sugers by yeast are very significant. The consumed sugers stopped on the $2^{\text {nd }}$ day of fermentation. After experiencing a phase of adaptation, the microbes start splitting at low speed because the new start adjusting (Fardiaz, 1988).

Based on Figure 7 bellow showed that until the $2^{\text {nd }}$ day decreased in reducing sugar levels very quickly. This situation was due to $S$. cerevisiae yeast that still entering $\log$ phase, microbes are rapidly dividing and constant follow a logarithmic curve. The increasing of the sugar consumption indicated that substrate fermentation has not converted to ethanol complately. The substrate will continue to decrease the length of the fermentation process. 


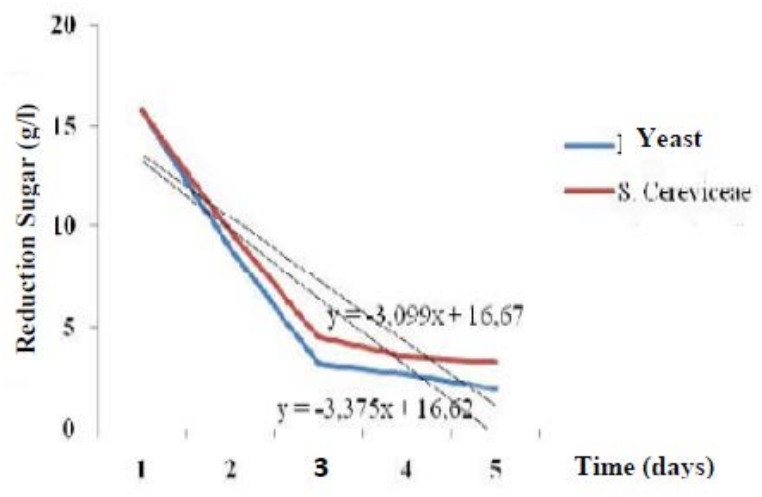

Figure 7. Decreasing of reduction sugar

In the fermentation process using the inoculum of $S$. cerevisiae yeast and pure, able to converted sugar into ethanol of $0,87 \mathrm{~g} / \mathrm{l}$ and $0.79 \mathrm{~g} / \mathrm{l}$ respectively, with substrate utilization efficiency average were $87.53 \%$ and $78.90 \%$. Theoretical conversion of ethanol formation from glucose is $51 \%$ with the following reaction:

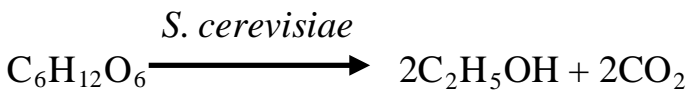

Based on the above equation, 1 mole of glucose can produce each 2 moles of ethanol and $\mathrm{CO}_{2}$. While from $1 \mathrm{~g}$ glucose theoretically be produced $0.51 \mathrm{~g}$ ethanol (Maiorella et al., 1981 in Ega et al., 2013). In fact, Isroi (2013) stated that ethanol derived only about $90 \%$ of the theoretical results because glucose was also used for the growth of S.cereviceae. Then the possibility of ethanol produced by $60-70 \%$ or $0.357 \mathrm{~g}$ ethanol per $1 \mathrm{~g}$ of glucose.

In this study, sugar was used in the fermentation process amounted to $15.61 \mathrm{~g} / \mathrm{l}$. If the whole substrate sugar was converted to ethanol yield $10.23 \mathrm{ml}$ of ethanol. On the condition of fermentation using yeast inoculum obtained fermentation efficiency by $87.53 \%$, the theoretical ethanol obtained was $8.9 \mathrm{ml}$ and $8.1 \mathrm{ml}$ inoculum for the fermentation process using a pure culture fermentation of S. cerevisiae with $78.9 \%$ efficiency.

Based on this research, it was known that the performance of yeast derived from yeast inoculum better than pure cultures of $S$. cereviseae. Significant differences in the results indicated the possibility of the use of yeast culture that was cheaper and easy to apply in small and medium industries.

\section{CONCLUSSIONS}

1. Euchema cottonii hydrolysis optimal conditions, i.e. at a concentration of $2 \%$ $\mathrm{H}_{2} \mathrm{SO}_{4}$ for 120 minutes at a temperature of $80^{\circ} \mathrm{C}$ which results in reducing sugar 15.61 g/l; Hydroksymetilfurfural (HMF) 5.03 g/l.

2. Fermentation of E. cottonii hydrolyzate by yeast was able to achieve the substrate utilization efficiency of $87.53 \%$ and a consume in reduction sugar to the remaining $1.96 \mathrm{~g} / \mathrm{l}$ on the fifth day of fermentation.

\section{ACKNOWLEDGEMENT}

The authors are gratefull to all researcher members and The Indonesian Goverment, specially Buton Province. This study was supported by the program of Master Plan of The Indonesian Economic Accelerated Development, Assigment No. LPPMUGM/2402/LIT/2013.

\section{REFERENCES}

Candra, Krishna Purnawan, Sarwono, Sarinah. 2011. Study on Bioethanol Production using Red Seaweed Eucheuma cottonii From Bontang Sea Water. Journal of Coastal Development Volume: 15 Number: 1, October $2011: 45-50$.

Clark, T. Dan K. L. Mackie. 1984. Fermentation Inhibition in Word Hydrolisates Derived from the Softwood Pinus radiate. J. Chem. Bioetechnol. Vol. 34B: 101-110.

Fardiaz, S. 1988. Physiology of Fermentation. Resource and Information Institute, IPB Bogor.

Howard, R.L., E. Abotsi, J.E.L., Rensburg, V. and Howard, S. 2003. Lignocellulose Biotechnology: Issues of Bioconversion and Enzyme Production. African Journal of Biotechnology. 2(12):602 - 619.

Iranmahboob, J., Nadim, F., dan Monemi, S., 2002. Optimizing acid-hydrlysis: a critical step for production of ethanol from mixed wood chips. Biomass and Bioenergy, 22: $401-404$.

Irawan, D. dan Zainal, A. 
2012. Hydrolysis Processing of Organic Waste Being Sugar with Hydrochloric Acid Catalysts. In the Journal of Chemical Engineering: Volume 6, No 2 no page 3640.

Isroi. 2014. Bioethanol Production Calculation in http://isroi.com/ 2010/06/14/bioethanol-production calculation/ Accessed on 15 May 2014.

Marine and Fisheries Ministry. 2011. 2012, KKP Seaweed

Production Targets 5.1 Million Tons. In www.kkp.go.id.

Mangunwidjaja, D dan Suryani.A. 1994. Technology Bioproses. Penebar Swadaya, Jakarta.

Meinita MD, Yong-Ki, H., and Gwi-Taek, J. 2011. Comparison of Sulfuric and Hidrochloric acids as Catalyst in Hydrolysis of Kappaphycus alvarezzii (cottonii). Bioprocess Biosyst Eng. (2012) 35:123-128

Nurdin, I.N. 2012. Evaluation of the Quality and Post Harvest Handling Seaweed Eucheuma cottonii Buto $\mathrm{n}$ in Southeast Sulawesi Province. Thesis Graduate Program Faculty of Agricultural Technology Universitas Gadjah Mada.

Palmqvist, E., and Hahn-Hägerdal, B., 2000. Review paper. Fermentation of lignocellulosic hydrolysates. II: inhibitors and mechanisms of inhibition. Bioresource Technology, 74, 25-33.

Park, J.-H., Hong, J.-Y., Jang, H. C., Oh, S. G., Kim, S.-H., Yoon, J.-J., and Kim, Y. J. 2011. Use of Gelidium amansii as a promising resource for bioethanol: A practical approach for continuous diluteacid hydrolysis and fermentation. Bioresource Technology, 108, 83-88.

Prescot, S. C. dan C. G. Dunn. 1981. Industrial Microbiology. McGraw-Hill Book Co. Ltd. New York

Puspawati, S., Wagiman, Makhmudun, A., Darmawan, A. N., dan Haslianti. 2015.

The Production of Bioethanol Fermentation Substrate from Eucheuma cottonii Seaweed through Hydrolysis by Cellulose Enzyme. Agriculture and Agricultural Science Procedia 2015, Vol. 3 200-205.

Samsuri, of

M. 2007. Cellulosic
Production Through Baga for Saccharificati on and Fermentation Simultaneously with Xylanase enzyme. Jakarta: Makara Technology.

Tan, I., Man K., and Keat, T. 2013. Hydrolysis of macroalgae using heterogeneous catalyst for bioethanol production. Carbohydrate Polimers Science Direct 94 (2013) 561-566

Wiratmaja, I.G., I.G.B. Wijaya, K., dan I. N. Suprapta, W. 2011. Making the Second Generation of Ethanol by Utilizing Waste of Eucheuma Cottonii as Raw Materials. Scientific Journal of Mechanical Engineering.Vol. 5 No.1: 75-84. 